\title{
Assessing the Impact of Barrack Environment on Independent Mobility of Children in the Military Barrack of Nigeria
}

\author{
Tosin DAODU, Ismail SAID, John k Ologbonde
}

\begin{abstract}
Independent mobility of children living in the barrack is declining over the last four decades due to its unfriendly environment. There are limited studies on children-environment relationships in Nigeria, especially in the barrack. Available studies from social sciences and public health studies lack policy connection with the child-friendly environment for improved independent mobility. Hence, this study aimed to develop a child-friendly barrack environment policy framework for enhanced independent movement of children. The safety and security, barrack environmental quality, basic services, quality of housing, and children's participation were five characteristics of a child-friendly environment considered. They exogenously predicted improved independent mobility of children in the barrack. On the other hand, the endogenous construct consists of the land-use change, destination accessibility, home range, travel time, and population density of the barrack. A total of 390 parent and primary school children aged 5-12 living in the Nigerian Air Force Barrack in Kaduna jointly assessed the five barrack environment characteristics and five indicators of children's independent mobility. The survey questionnaire was analysed using SPSS and PLS-SEM. Consequently, the principal component analysis showed high factor loading for the five characteristics and four independent mobility indicators except for the land use that fell below 0.7 thresholds. The outer weights of the reflexive measurement items were high which signified strong correlations. Hence, barrack environment characteristics strongly predicted improved independent mobility of children. Thus, the structural model's path coefficient of 0.585 explained $58.5 \%$ variance in the independent mobility of children in the barrack residential area. The coefficient of determination $R^{2}$ value is 0.342 , and the p-value is at 0.000 level of significance. It provided an environment planning policy framework to monitor interventions and halt the declining rates of children's independent mobility in the military barrack of Nigeria. The conceptual framework developed is applicable in the para-military barrack, housing estates and compact cities in African countries including Nigeria.
\end{abstract}

Keywords: Child- friendly Barrack Environment, Independent Mobility, Planning Policy

Revised Manuscript Received on November 12, 2019.

* Correspondence Author

Tosin Daodu*, PhD Candidate, Department of Architecture, Faculty of Built Environment and Surveying, Universiti Teknologi, Malaysia 81310 Skudai Johor Bahru, Malaysia Email: daodutosin1@gmail.com

Ismail Said, Professor, Greenovation Research Group, Faculty of Built Environment and Surveying, Universiti Teknologi Malaysia

81310 Skudai Johor Bahru, Malaysia Email: 2ismailsaid@gmail.com,

John K Ologbonde, Department of Quantity Surveying, Faculty of Environmental Studies, Rufus Giwa Polytechnic, Owo, Ondo State, Nigeria Email: 3johnologbonde@gmail.com

(c) The Authors. Published by Blue Eyes Intelligence Engineering and Sciences Publication (BEIESP). This is an open access article under the CC BY-NC-ND license (http://creativecommons.org/licenses/by-nc-nd/4.0/)

\section{INTRODUCTION}

The barrack is where children live, learn about society, explore, observe, absorb their values, and acquire a sense of belonging. Although home, school, and playground play a role in children's learning, a policy of setting aside child play spaces goes a long way to meet the developmental goals. The quality of the environment or outdoor contributes immensely to their independent play and development. Children want to learn how they, their home, street, and environment fit into broader society. Their independent mobility, accessibility, and interaction help to learn how the community works. Knowing what is safe and risky, who to trust and not trust. Removal of children from the neighbourhood means exclusion from environmental experiences. It results in a loss of skills associated with decision making and independent mobility of children. Home range and travel time concepts in the residential area of barrack are essential indicators. For instance, children need to experience traffic calming so that they are safe for children to walk, cross and play in the barrack. Understanding of heavy traffic is required in barrack to improve the independent mobility of children. However, the advancement of environmental child-friendliness is a community-based concept focused in this paper. It is beyond an individual level [1] It aimed at integrating children experiences to issues of planning by making them participate in planning decisions. The physical environment connects children's place concept and immediate environment. Similar to military barracks communities in Nigeria. Strategies aimed at providing a range of physical activity and social settings were in past studies [2]. The environment setting covered the immediate background to the neighbourhood and citywide location of children [2]. It's also in consonance with Horelli's theory on child-friendly structures. The network of places with meaningful activities for children to experience a sense of belonging lonely or in a group [1]. Consequently, this research combined both children's experiential knowledge with parent perception in a survey questionnaire. Environment characteristics identified and measurable independent mobility indicator specific to barrack setting were used [3].

Besides, a child interacts with the physical environment needs to satisfy four essential criteria which include movement, comfort, competence and control. The essence of intellectual development in children involves the ability to locate himself freely in space by assuming different postures, create his boundary and access to diverse territories [3]. Moreover,

Published By:

Blue Eyes Intelligence Engineering \& Sciences Publication 
The need to feel comfortable and secure in their environment is necessary as settings are perceived to be healthy by providing a varied degree of stimulation for senses. Similarly, barrack environment requires basic characteristics to predict a model of independent mobility. children participation as well as safety and security. Therefore, a beneficial environment allows children to achieve fulfilment in their personal needs. It also includes executing the task successfully, able to control their play materials and movement from one place to the other. privacy, predictions, and proper orientation. All of which a child-friendly barrack environment must seek to achieve independent mobility of children and well-being without jeopardising the essence of security. In developing a policy of independent mobility that benefits children in the barrack, a vital issue is how a system can be designed so that children are a significant player. The micro-level that has to do with decision making about children's everyday life is essential. It has been the focus of many kinds of research regarding issues such as the independent mobility of children and play ranges [3]. The significance of the quality everyday spaces in which children identify and live are made and remade. Children, when afforded opportunity and sense of belonging are incredibly versatile and skillful negotiators of various context and useful in transferring skills in one domain to the other realistically. Children see the whole city not just a small demarcated area as play space. Children require absolute freedom from traffic dangers, injury, and too much control by an adult before they explore their environment [4],[5]. Quality housing amenities, safety and security are a consideration especially a link between home range, travel time, and destination accessibility. The appropriate framework of independent mobility of children can be developed. Meanwhile, the groundwork regarding the acceptance of the fact that parent and children play a central role in planning and decision making is an essential factor. In developing such a framework, there is a need to identify indicators of children's independent mobility peculiar to the military barrack milieu. The design of housing with less space for outdoor activities especially in the airmen quarters, as well as more internal space in the housing design of officers' quarters, encourage sedentary lifestyle for children [3].

In the barrack, parental perception of the independent mobility of children in home, school, and playground is another factor worth considering. The continued decline in freedom of movement by children needs the cooperation of parent and children to achieve success in planning policy. For instance, parent belief that children require a playground to play apart from home and school [6]. Similarly, parks and playground are not substituting for a truly child-friendly city [7]. The impact of environment and competing demand on their time is a consideration in any planning policy of children independent mobility. A parent often imposes it unless it is negotiated. Parent continued to insist on keeping children busy with extra-curriculum activities like music, sports, and maths coaching, among others. Children also contribute by spending most of their times on the internet, computer games, and television. A survey questionnaire was administered to parent and children living in the barrack to be answered jointly as a family. It keeps away the issue of parental consent among the independent mobility of They include environmental quality, housing, basic services, Likewise, a child needs control over his environment for

children's indicators in this prediction. Many parents in the military barracks permit their children above 12 years to attend secondary schools outside the barrack. The middle childhood, mostly in primary school, are often restricted to the school environment and play areas within the barracks. Thus, the population of elementary school children seem to outnumber secondary school children residing in the barracks community. More so that military boarding facilities are mainly for secondary schools. It is worthy to state here that Nigeria's education system and admission policy of six years in elementary, three years in junior secondary, three in senior secondary and four years of higher learning in a tertiary institution. It is structured in Nigeria's education policy as contained in section one, sub-section 5 that primary education starts from the age of 5 or 6 for eligibility [8].

\section{LITERATURE REVIEW}

The literature review covers the trend in child-friendly environment studies and the concept of children's independent mobility. It also looked briefly into the child-friendly environment and Independent mobility policy connections.

\section{A. Trend of Child-friendly Environment Studies}

The early multi-disciplinary studies of children and cities stem from the mid-nineteenth century. For instance, housing conditions within the Industrial Victorian town were recognised as a significant factor of discomfort. The one-room system accommodating tenement housing was separated into single room apartment. In this case, the communal sharing amenities contained different types of manufacturing activities. The overcrowding nature involving children in such a single-room dwelling with adults was appalling and dangerous to children's quality of life [9] Similarly, communities surrounding the barracks in urban areas impact on housing and children [10]. It is made worst by socio-economic facilities like mammy market that harbours all sort of people from within and outside barrack. In Chicago, UK, and Australia, housing challenges was ameliorated by ensuring availability of urban play spaces for children. It emerged from urban planning debates. Playground provided the necessary space for child development which forms the design component of a modern environment. It enhances the interaction of children with an urban environment which continued to grow. Sociologists began to discover urban children characteristics in the 1930s [11]. It was in the mid-1960s that the first study began to use empirical research to explain how children relate to the urban environment. To this extent, the Government provide funds for research into children's play, giving playground, roads, and conditions within housing estates [12]. Generally, the $1970 \mathrm{~s}$ to the 1990s witnessed the emergence of multidisciplinary approaches to research. The ways children perceive their urban environment received worldwide attention in the 70s. It was a result of the establishment of the United Nations Educational, Scientific and Cultural Organisation (UNESCO). A ten-year programme centred on people-oriented solutions to environmental challenges [13]. The interdisciplinary approach involved a combination of social researchers, natural scientist, architect, planners and other urban environmental practitioners.

Published By:

\& Sciences Publication

(C) Copyright: All rights reserved. 
It aimed at examining the way small groups of young adolescents use and value their spatial environment [14]. The project was named Growing Up in Cities and described an international effort to understand young people's perspective on the urban environment [15]. Nigeria is a signatory to the UNESCO but lack policy framework for implementation. It led to the continuous decline in children's independent mobility in Nigeria, including the military barrack.

Previous research took an interest in unstructured space like a football field, mammy market, and house yard [3]. These formed places where children meet and organise their play [14]. The structured children's playground specifically built for children's use, has been abandoned in the barrack. Other areas of interest are home to school and play area journey as a meeting place for children. The average travel time budget required for various destinations were calculated at a minimum of 5 minutes and a maximum of 20 minutes walkable distances in the barrack. These are often affected by the quality of the barrack environment. While, children's independent mobility indicators are often influenced by parental fear of traffic, injury to children, lack of spatial knowledge resulting from poor children's participation. This study was able to recognise that parents and children have different perceptions of barrack places that needed to be harmonised. Just like researches on urban children in the 80s had parallel themes raised in previous decades, emphasis in this study is the independent mobility of children in barrack environment. However, decision-makers had often assumed urban environmental needs of children [16]. Later research also looked at environmental differences for inner-city, suburban children and those living in more privileged environments. They attempted to understand how children perceived the quality of their surrounding environment [17]. By the end of the 1980s, more sophisticated statistical approaches were developed to define environmental quality, integrating children's well-being [18]. In this study, a quantitative approach was used to predict parent perception of barrack environment characteristics on the independent mobility of children. Thus, it is necessary to understand children's engagement with the environment in future research.

Furthermore, destination accessibility issues for children existed in the 70s and 80s, and it became more significant in the early 90s. Children and youth in cities had continued to be excluded from safely utilizing their neighbourhoods since the 1970s [19]. The crime rate, motorised traffic and poor quality of parks, playground and schoolyards were some of the factors attributed to this change as identified by Gaster and independent mobility of Australian children [20]. Finally, the challenges of destination accessibility and mobility faced by young children in their leisure activities [21]. This factor has incorporated as one of the measures of children's independent mobility of children's indicator in this study. In the 1990s and beyond, physical and medical issues such as obesity, reduction in physical activity and environmental challenges facing urban children emerged. Series of researches since the mid-1990s revealed increasing emphasis of a multidisciplinary approach. The urban environment allows children to develop social competencies and skills as they grow through an independent lifestyle in their neighbourhood. Children's ability to explore their environment helps their independent mobility [22]. Parental concern for child safety culminated to mobility restrictions as children are kept indoor [23]. This trend is towards restrictive independent mobility on how children learn about their immediate environment. It impacted on how children increase their home geographical range as they grow up [24]. The loss of unstructured urban space has also contributed to this trend $[25,26]$. Other researches focused on access to the local neighbourhood, social aspect, and child independence [27] and the relationship between the built environment and health [28].

Several past studies on child-friendly environment attempted to define the concept of environmental child-friendliness in various context. Themes were developed, integrating children into decision-making processes as essential criteria [29],[30]. However, they did not consider improved independent mobility concept for monitoring programme. This study adopted the definition by [31], as shown in Figure 1. The study factorised ten normative dimensions which include housing and dwelling, basic services, participation, safety and security. Family, peers and community, urban and environmental qualities. Provision and distribution of resources and poverty reduction. Ecology, sense of belonging and continuity as well as good governance. Research by Horelli (2007) factorised into three, which included safety and security, urban and environmental qualities, and basic services as mentioned by Finland children and in Sweden [32]. These findings are somehow consistent with the earlier results of the Growing Up in Cities project [13], in which child-friendliness is too broad [2]. She argued that a child-friendly city is an expression of where children relate and how different Child-Friendly City (CFC) initiatives in Australia have supported physical and social transformations [33]. They viewed children's independent mobility as children's possibility to explore the open space freely. Nevertheless, young children needed to be involved in community development processes and get familiar with their environment [34]. It was believed that children are most often more knowledgeable on how the environmental decisions that impact their lives and community. Hence, children participate in community development is beneficial in learning a new skill and a sense of control. The diversity and complexity of the urban environment appear to be a critical factor among multiple variables impeding independent mobility of children. Likewise, the barrack has a pressing need for re-planning of barrack space that encompasses new idea and inclusive policy [3].

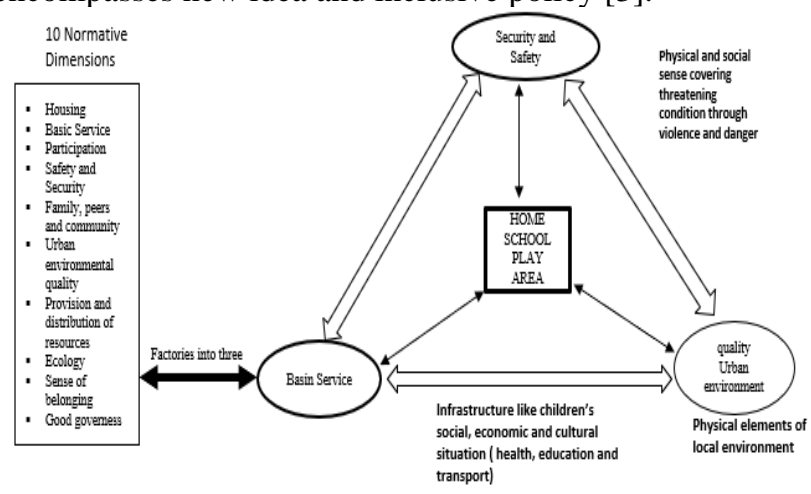

Fig. 1: Horelli theoretical framework for assessing child-friendly environment

Published By:

Blue Eyes Intelligence Engineering

\& Sciences Publication

(C) Copyright: All rights reserved.

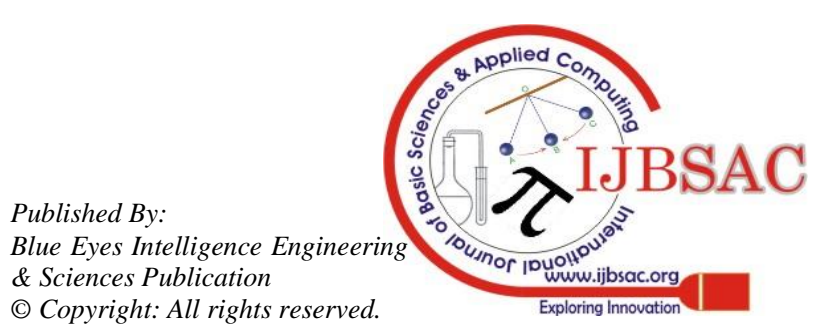




\section{B. Concept of Child-friendly Environment and Independent Mobility of Children}

Child-friendly built environment is significant for children's physical, mental, spiritual and social growth [35]. Thus, what constitutes a child-friendly built environment was explained [4],[32] Similarly, the built environment and child-friendliness were in two ways [36]. These included children's liberty to move around without adult supervision and chances to achieve environmental affordances. However, this study concentrates on independent mobility of children in a gated barrack community. The three settings where children relate freely in barrack residential environment were considered in this study in line with the previous studies [3]. These include the home, school, and play area that are significant for the independent mobility of children. The quarters, street and school existing poor-quality environment (see Figure 2).
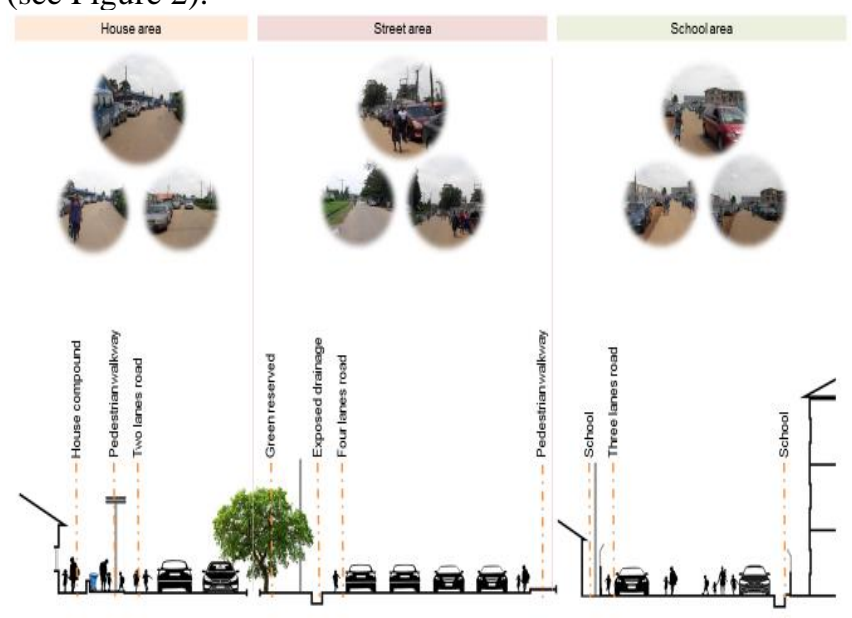

Fig. 2: Existing barrack environment situation that

\section{hinders the independent mobility of children}

On the other hand, independent mobility was conceptualised by Hillman and his colleagues in their early 1990 s studies. It merely refers to children's freedom of active movement and play outside the home environment within a territorial range, at a given time, destination, and licence from parents without adult accompaniment (Hillman et al., 1990; O'Brien et al., 2000). It is essential for children's physical, social and cognitive development. The IM contributes to the acquisition of physical activity [37]-[38], it also allows children learn through independent interaction in their environment. Thus, the knowledge they acquire interacting with place contribute to self-identity, safety, and make them socially competent [39]. In health researches, independent and mobility have been used variously to describe childhood relationships [40]. Despite these health benefits of independent mobility for children, this behaviour has continued to reduce all over developed countries in America and Europe in recent times [41]-[42]-[43]. Consequently, much other research that compared the older generation indicated that children were not likely to travel without supervision in their neighbourhood environments. It includes destinations like parks, during playtime [45]-[43]. The quest to increase housing stock has led to the conversion of open spaces for children play into shopping and event centre [3].

Furthermore, Mobility was also considered as a cultural function to construct personal identity [45]. The military barrack conformed with the mobility definition in the study owing to the land use mix nature, social activities and interaction of children. Recently, modernisation and advancement in technology have brought another dimension into monitoring independent children with the use of mobile phones [40]. It further reinforced the fact that independent mobility is a social construct that must reflect recent societal changes. This resultant effect of advancement in technology has equally influenced the independent movement of children in the barrack milieu of Nigeria. Several reasons adduced for the reduction in the independent mobility of children. To the extent that researches explored various views that showed consistency in parental safety concerns as one of the factors responsible [46]-[47]. Parental safety consciousness was found to be accountable for accompaniment and motorised travel mode choice that seem to override benefits of independent mobility of children in many countries [44]-[41]-[48]. The media reports of blanket children's kidnapping and abduction across Nigeria are some experiences responsible for parent's fear of safety in the barracks. On the current global trend of children's independent mobility, researches covering more than four decades have shown a decline [49]-[50]-[51]. The most important study to date used children's independent mobility data from 16 countries including Australia, Brazil, Denmark, England, Finland, France, Germany, Ireland Israel, Italy, Japan, Norway, Portugal, South Africa, Sri Lanka and Sweden [42]. In Africa, the level of children's independent mobility is often determined by income. Children from low-income experience a higher level of independent movement than their counterpart from a high-income background [3]. It was similar to the situation in the military barrack, where officers and airmen children are segregated by income and status. The airmen children enjoy a higher level of independent mobility than children living in officers' quarters [3].

\section{Child-friendly Environment and Independent mobility Policy Connections}

The built environment professionals such as architects, landscape architect, planners and policymakers are stakeholders in shaping the environment. It eventually shapes children and influences their lives and experiences in society. They concentrate on land use to ensure development control, policy formulation and implementation. Children's needs and views need consideration in development and policy planning. The decision they take, policies they implement and the developmental trend they support have direct influences on children's lives and well-being. In the Nigerian Air Force, the directorate of works and services have professionals expected to implement planning policies. How well children have been integrated remains the question to answer. The 1990s witnessed the inclusion of children as special consideration in the planning process of the environment that shapes them. It was ensured through the UN CRC [52] in articles 1,3, and 12. It states that, in the convention that children's environmental, social and participation rights will be supported. The motivation for children in planning is the creation of a child-friendly environment. A city that works for children works better for the majority.

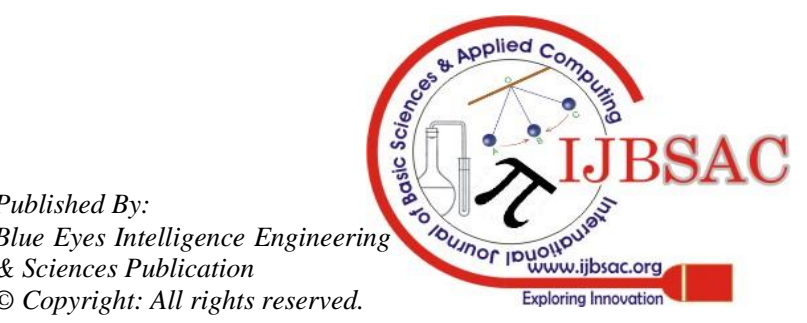


In the process, physical change continues to occur, notably the redesign of the city which impacts the lives of children. Meanwhile, transport development has led to the separation of the connection between home, school, activities reduces the opportunity for children to develop their independence. Children and planning policy connection are essential in a child-friendly barrack community for improved independent mobility. The current situation in towns. The quest to solve the shortage of accommodation which has reduced open spaces is a concern. Population increase and car availability in a smaller built-up area and development of gated barrack community impact on children's mobility. Children's exclusion from the outdoor environment and a decline in independent mobility of children is an issue of growing concern. Interestingly, if society has children well-being and safety as a priority in the cities, all children deserve good living standard and quality environment that promotes independent mobility. Thus, open space is essential for children as social space in the barrack, yet their access to this space is subject to growing social and physical retrains.

\section{The Study Area} covered a total land area of approximately 2,368 hectares or $23.68 \mathrm{~km}^{2}$ (see Figure 3). The population density was estimated at 910.143 persons $/ \mathrm{km}^{2}$ in 2018. The barrack is bordered in the North-east by Rigachikun village, Kawo community in the South-East, Mando community along the South-West, and the Nigerian Defence Academy permanent site towards the West. Besides, NAFB's establishment was strategically located in Kaduna following the regional arrangement in Nigeria before the state creation in 1976. Kaduna state accommodates many tertiary institutions including public universities, and military institutions like Armed Forces Command and Staff College Jaji, Nigerian Defence Academy, College of Aviation, Artillery training school, Navy music schools, and military training depots. Military companies such as Nigerian Defence Industry Cooperation, army workshop, and NAF companies are located in the state. The NAFB in Kaduna is the focus of this research. It is home to the Headquarters Training Command (HQTC) which was recently split into the Air Training Command (ATC) and Ground Training Command (GTC). The Headquarters of the ATC remained in Kaduna while the GTC Headquarters relocated to Enugu state, the command still maintained its training centres in Kaduna. It is the second-largest Air Force barracks in Nigeria, and the command currently ranked fourth in the hierarchy of NAF commands. As earlier noted, the presence of training institutions attracts young people desirous of joining the service and soldiers attending various basic and upgrading courses for promotion. The barrack accommodates a tertiary institution recently upgraded to university status, two secondary schools, one Air Force primary school, public primary school, and two Nursery schools. The NAF educational policy of $70 \%$ personnel children and $30 \%$ civilian children ratio has not been effective. Thereby the majority of personnel children attends primary school outside the barrack. The primary school within the barrack can admit 1,600 in a year while the population of residents has increased to over 20,000 with a quarter been children below shopping, and play areas. The geographical separation of barracks is experiencing urban pressure from neighbouring

The Nigerian Air Force Barrack (NAFB) in Kaduna

18 years of age. On the other hand, the rate of influx into the barrack has grown tremendously. It is mainly due to the new expansion and quest for more housing. The compact residential built-up area is congested and not environmentally and transit-friendly [3]. Meanwhile, these have a far-reaching effect on the child-friendliness of the built environment and independent mobility in the barracks.
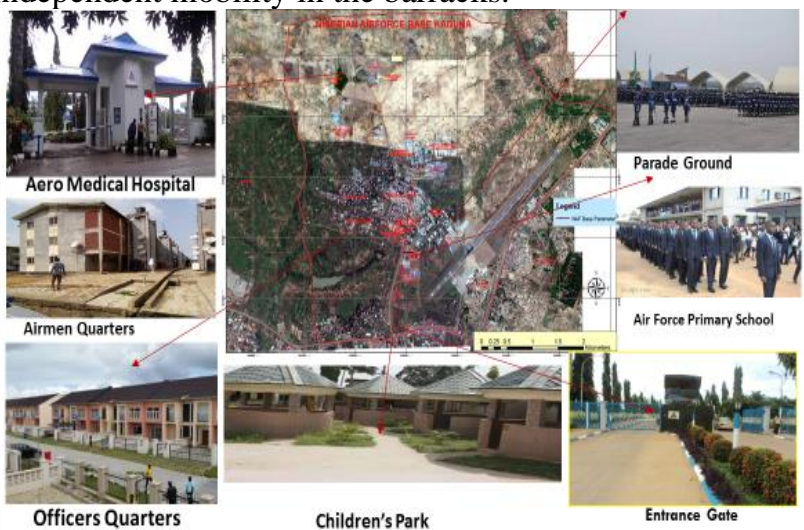

Fig. 3: Nigerian Air Force Barrack in Kaduna

\section{RESEARCH METHODS}

The survey questionnaire was administered to parents and children living at NAFB in Kaduna. Opinion, experience and level of satisfaction on issues of a barrack environment impact on independent mobility of children were elicited. Data collected from barrack census results, directorate of personnel management, provost squadron at the NAFB, books, thesis and airman magazine were the secondary source of data. The study area was classified into officers' quarters (MOQ) which consist of married and single. The airmen quarters are senior non-commission (SNCOs) and non-commission officers (NCOs) residential quarters. The questionnaire administered in each sample size differs following unequal sizes of the quarters and population densities. Transit quarters for officers and airmen were excluded especially those occupied by single personnel. Household representatives were allowed to fill a questionnaire with children on behalf of staff on posting. It is to ensure a broad scope for examining the independent mobility of children in military barracks. Moreover, four survey assistants were selected among personnel with qualifications ranging from diploma and degrees holders. They were briefed on the mode of response to questions. It was in addition to efforts made to serve the respondents personally by the researcher. A total of 500 questionnaires were administered in case of refusal to accept the survey by some respondents in the barrack. The number returned was 420 out of which those not correctly filled were sorted to have a minimum of 390 representing 92.9\%. However, it is within the acceptable upper limit of 384 required for analysis (53). The parent and children perception on barrack environment characteristics influencing independent mobility of children were analysed using SPSS 22 and SEM-PLS software. The scale is ordinal scale with a 5-point Likert scale. Data distribution is not likely normally distributed like having 10-point Likert range. It is, therefore, safer to use PLS-SEM to develop path analysis as the normal distribution of data is not usually desirable. 
The PLS-SEM is a statistical modelling technique and tool to predict in new and different ways [54]-[55].

The community based theoretical framework underpinned the study [31]. This research factorised the ten normative dimensions into five. These are the barrack environment quality, housing quality, provision of basic Results were further analysed using Structural Equation Model (SEM -PLS). The hypothesis developed was to know if there is any significant effect in barrack environment characteristics predicting independent mobility. Thus, a null hypothesis and an alternative hypothesis was as follow:

H0: Barrack environment characteristics have no significant effect on the independent movement of children in the military barracks

H1: Barrack environment characteristics have a substantial impact on the independent mobility of children in the military barrack.

The independent mobility of children indicators included destination accessibility, population density, home geographical range, average travel time, and land-use change. The reliability and sample suitability test were preliminary data examination performed. Then, the exploratory factor analysis was conducted to reduce the and structural model were evaluated.

\section{A. Test of Reliability}

Test of reliability was carried out to verify the consistency of variables in measuring the barrack environment characteristics (exogenous latent construct) and independent mobility of children's indicators (endogenous latent construct). Inter-item correlations and internal consistency were examined following the methodology design for measuring independent mobility of children and environmental friendliness of barracks community. Endogenous construct included the destination accessibility (B1), population density (B2), home geographical range (B3), and average travel time (B4). While the exogenous constructs are the barrack housing environment characteristics. They included the barrack environmental quality $(\mathrm{C} 1)$, quality of housing amenities (C2), children's participation (C3), basic services (C4), as well as safety and security (C5).

\section{B. Sample Suitability Test}

The sample suitability test was carried out with Kaiser-Meyer-Olkin (KMO) and Bartlett's test. This confirmed satisfaction in the strength of association between items in a questionnaire administered to parent and children. The outcome showed sample acceptability of 0.967 , which is well above the threshold of 0.7 Cronbach alpha coefficient. It means that responses and strength of relationship among indicators and characteristics considered in this study are adequate for analysing their influences on the independent mobility of children in military barracks.

\section{RESULTS AND DISCUSSION}

\section{A. Exploratory Factor Analysis}

Exploratory factor analysis (EFA) brings measurable items together to form a structure in the model. Barrack environment characteristics and independent mobility of children's indicators were grouped into components. It was to investigate their relevance at the same time test for validity and contribution to the perceived model. The PCA and EFA services, children participation as well as safety and security. numbers of measurement items. After that, the measurement

used extraction based on varimax rotation (see Table 4). The threshold for factor extraction of Eigenvalue $>1$. Factor loading above 0.7 was retained [56].

Table 4: Exploratory Factor Analysis

\begin{tabular}{|c|c|c|c|c|}
\hline \multicolumn{5}{|c|}{ Rotated Component Matrix ${ }^{a}$} \\
\hline & \multicolumn{4}{|c|}{ Component } \\
\hline & 1 & 2 & 3 & 4 \\
\hline \multicolumn{5}{|l|}{ Item } \\
\hline IMCI3(B3) & .925 & & & \\
\hline IMCI2(B2) & .922 & & & \\
\hline IMCI4(B4) & .916 & & & \\
\hline IMCI1(B1) & .865 & & & \\
\hline ВEC3(C3) & & .835 & & \\
\hline BEC1(C1) & & .830 & & \\
\hline BEC4(C4) & & .827 & & \\
\hline BEC5(C5) & & .826 & & \\
\hline BEC2(C6) & & .763 & & \\
\hline \multicolumn{5}{|c|}{$\begin{array}{l}\text { Extraction Method: Principal Component Analysis. } \\
\text { Rotation Method: Varimax with Kaiser Normalization. }\end{array}$} \\
\hline \multicolumn{5}{|c|}{ a. Rotation converged in 6 iterations. } \\
\hline
\end{tabular}

B. Measurement and Structural Model Assessment

The statistical analysis displayed in Table 4 showed acceptable factor loading above 0.7 thresholds for all component items of barrack environment and independent mobility of children. Result of reflective measurement evaluation further showed the outer loadings of all reflexive measurement indicators $>0.7$. The composite reliability (CR) $>0.7$ and convergent validity (AVE) $>0.5$. The value of Heterotrait-Monotrait (HTMT) is greater than $9(<0.9)$. Hence, the null hypothesis HO was accepted. It, therefore, fulfilled the discriminant validity in the evaluation (see Table 5). Notably, HTMT is a new tool for discriminant validity in PLS-SEM. The structural model assessment included path analysis of barrack environment predicting independent mobility of children in barrack (see Figure 4). Further to this, path significance $\left(\mathrm{F}^{2}\right)$ for barrack environment characteristics predicting independent mobility of children was conducted, as shown in Figure 5. Consequently, the structural model showed a path coefficient of 0.585 which explained $58.5 \%$ variance in the independent mobility of children. The coefficient of determination $\mathrm{R}^{2}$ value is 0.342 . Multi-collinearity (VIF) result is less than the value of 3 , indicating that collinearity was established in the model. The commonly used critical values for the two-tailed test are 1.65 significant level of $10 \%$ and 1.96 significant level of $5 \%$. In this study, the empirical t-value of 11.85 obtained from path significance is larger than the critical value of 1.96. Thus, the $\mathrm{p}$-value is at 0.00 level of significance.

Based on these results, PLS-SEM estimated coefficient in the path model that maximised $\mathrm{R}^{2}$ values (0.342) of the independent mobility of children. Therefore, barrack environment characteristics have a powerful effect in predicting the independent mobility of children in the military barrack. The finding substantiated the hypothesised relationship between the barrack environment and the independent mobility of children living in the barrack. It indicated that the barrack environment characteristics have a robust significant impact on the predicted model.

Published By: 
This finding is consistent with [57], which considered the development of a systems model to visualise the complexity of children's independent mobility. The study and several others developed linear causal pathway models to understand the influences on children's independent mobility in various context using built environment factors. On the contrary, this study on military barrack children considered child-friendly environment characteristics underpinned by Horelli's theoretical framework. Children's participation was the most influential rated by the parent and their children (0.99). It means that NAF authorities and professionals need to ensure more participation of children in planning policy of environment that shapes them. The provision of basic services at proximate distances to the residential quarters, environmental quality and the issue of security and safety in the barracks were at par (0.98). It means they are essential characteristics required to make the barrack child-friendly to improve their independent mobility. The housing quality and maintenance are also significant factors that hinder the independent mobility of children. It has an outer weight of 0.92 . Hence attention is required to improve the quality of housing, especially in the airmen quarters. It included the building structure and associated facilities for children's comfort.

Table 5: Summary of Reflexive Measurement Evaluation

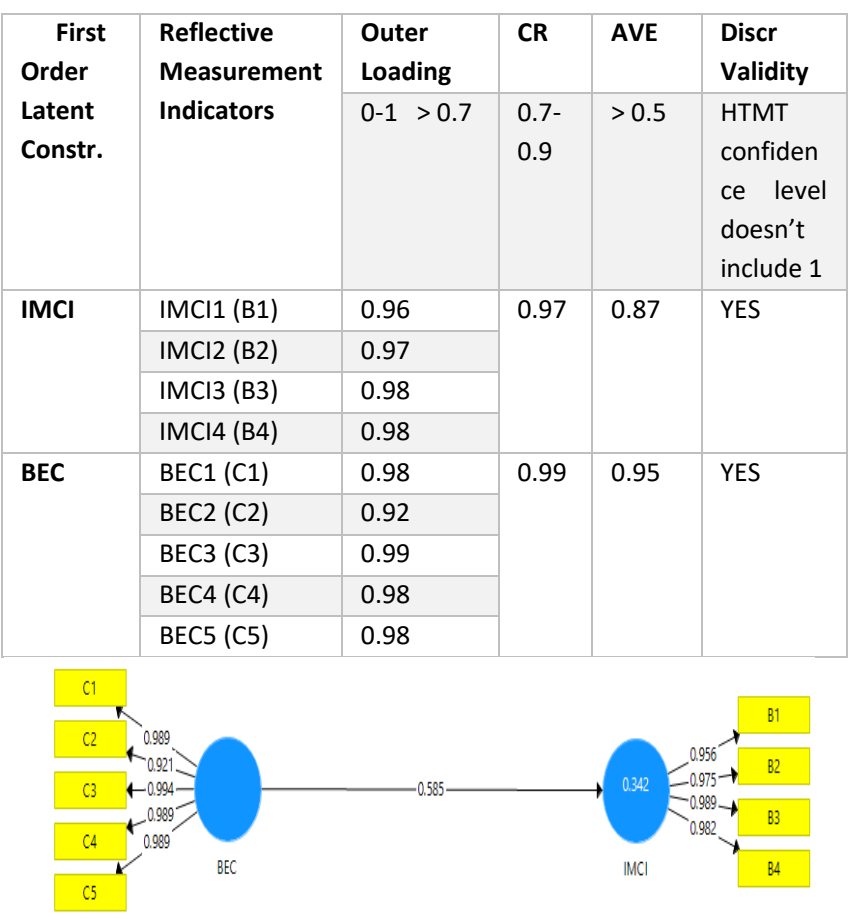

Fig. 4: Path analysis for barrack environment characteristics predicting independent mobility of children

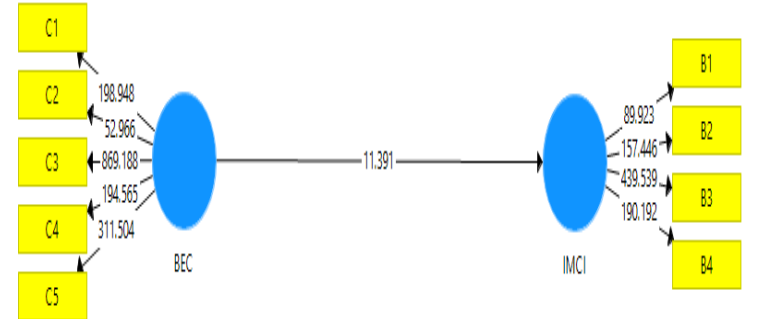

Fig. 5: Path significance $\left(f^{2}\right)$ for barrack environment characteristics predicting independent mobility of children

\section{CONCLUSION}

An improvement in the level of independent mobility of children requires a child-friendly barrack. The barrack environment quality, housing quality, security and safety, basic services and children participation were the necessary characteristics. Thus, investment in basic infrastructure and services, improved barrack environment and housing quality, as well as security and safety, were essential criteria in the policy framework. Safety and security in barracks with strict adherence to regulation as well as children participation was the leading influential characteristics in barrack environment. Barrack needs to address environment characteristics in support of population growth, destination accessibility, home rage and travel distance. It will mitigate the continuous decline in children's independent mobility. The policy framework will enhance the independent mobility of children living in the military barrack through a policy guide for professionals in the built environment such as the landscape architects and planners. This conceptual model provided a useful policy framework for evaluating how to develop and monitor interventions to halt the declining rates of children's independent mobility in a Child-friendly barrack. It is applicable in para-military barracks, housing estates and compact cities in the developing countries of Africa, including Nigeria.

\section{REFERENCES}

1. Horelli, L (1998). Creating child-friendly environments: A Case study of children participating in three European countries, Childhood 5, pp. 225-239.

2. Chatterjee, S. 2005. Children's friendship with place: a conceptual inquiry, children, youth and environment, 15 (1), pp. 1-26

3. Daodu, O. and Ismail, S. (2019) 'Assessing independent mobility of children indicators in the military barrack community of Nigeria', IJSRST Vol 6 (2): 531-546

4. Daodu, O. and Ismail, S. (2019) 'Effects of travel mode choice behaviour on independent mobility of children in the military barrack of Nigeria. $J$. of appl. sciences and environmental sustainability', 10 (5): $15-29$

5. Kyttä, M., Hirvonen, J., Rudner, J., Pirjola, I., Laatikainen, T., (2015). The last free-range children? Children's independent mobility in Finland in 1990 and 2010. J. Transp. Geography 47,1-12.

6. Tranter, P.J (1993) 'Children's Mobility in Canberra: Confinement or Independence? Monography Series No.7, Canberra: Department of Geography and Oceanography, University College, Australian Defense Force Academy.

7. Czaczynska-Podolska, M (2014) The impact of playground spatial features on children's play and activity forms: An evaluation of contemporary playgrounds' play and social value

8. Odukoya, O. (2017). Formulation and implementation of educational policies in Nigeria

9. Hall, P (2002) Cities of Tomorrow, $3^{\text {rd }}$ edn, Oxford: Blackwell Publishing.

10. Daodu, O. (2004) Housing Characteristics and effects on personnel productivity in the Nigerian Air Force: Unpublished MSc thesis submitted to the University of Ibadan, Nigeria.

11. Reckless, W. (1935) 'As sociologists enter child-development study', J. of Ed. Soc. 9 (2): 111-18

12. River, NJ: Merrill Prentice Hall.

13. Marcus, C. and Moore, R. (1976) 'Children and their environments: a review of research 1955-1975', Journal of Architectural Education, 29 (4): 22-5.

14. Chawla, L. (ed.) (2002) Growing up in an Urbanising World. London: UNESCO/Earthscan.

15. Lynch, K. (1977) Growing Up in Cities, Cambridge, MA: MIT Press. Maat, K. and Timmermans, H.J. (2009) 'Influence of the residential and work environment on car use in dual-earner households', Transportation Research Part A 43 (7), 654-664.

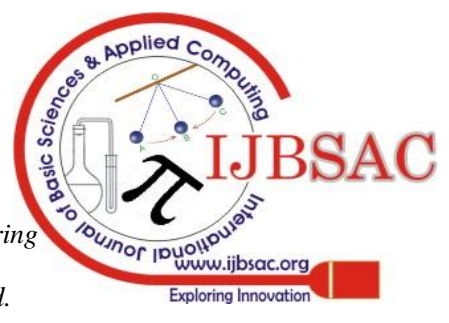


16. Chawla, L. and K. Malone (2003) 'Neighbourhood Quality in Children's Eyes', in P.

17. De Monchaux, S (1981) Planning with children in Mind: A Notebook for Local Planners and Policy Makers on Children in the City Environment, Sydney: NSW Department of Environment and Planning

18. Homel, R. and Burns, A (1985) 'Through a child's eyes: quality of neighborhood and quality of life', in Burnley, I. and Forrest, J. Living in Cities: Urbanism and society in metropolitan Australia Sydney: Allen \& Unwin.

19. Homel, R. and Burns, A. (1989) 'Environmental quality and the well-being of children', Society Indicators Research, 21:133-58.

20. Gaster, S. (1991) 'Urban children's access to their neighbourhood: changes over three generations', Environment and Behavior, 23(1):70-85.

21. Tranter, P., Whitelegg, J., 1994. Children's travel behaviours in Canberra: car-dependent lifestyles in a low-density city. J. Transp. Geography 2 (4), 265-273.

22. McMeeking, D. and Purkayastha, B. (1995) 'I can't have my mom running me everywhere' 'adolescents, leisure, and accessibility', Journal of Leisure Research,27 (4):360-378

23. Christensen, P.M., O'Brien, M., 2003. Children in the City: Home, Neighbourhood and Community. Routledge Falmer.

24. Collins, D. and Kearns, R. (2001) 'The safe journeys of an enterprising school: negotiating landscape opportunity and risk', Health and Place, 7 (4):293-306.

25. Christensen, P. (2003) 'Place, space and knowledge: children in the village and the city' in Christensen, P. and O'Brien, M.(eds) Children in the in the City: Home, Neighborhood and community, London: Routledge/Falmer, pp.118-141.

26. Rasmussen, K. and Smidt, S. (2003) 'Children in the Neighbourhood: The Neighbourhood in the Children', in P. Christensen and M. O'Brien (eds) Children in the City: Home, Neighbourhood and Community, pp. 82-100. London and New York: Routledge/Falmer.

27. Rasmussen, K. (2004) Places for Children - Children's Places. Childhood: A Global Journal of Child Research, 11 (2), 155-173.

28. Tranter, P., Sharpe, S., 2012. Disney-Pixar to the rescue: harnessing positive effect for enhancing children's active mobility. J. Transp. Geography 20 (1), 34-40.

29. 28. Evans, G. (2003) 'The built environment and mental health', Journal of urban Health: Bulletin of the New York Academy of Medicine, 8(4): 536-55

30. Gill, T. (2008) 'Space-oriented children's policy: creating child-friendly communities to improve children's well-being', Children and Society 22, 136-142.

31. Broberg, A., Kyttä, M. and Fagerholm, N., (2013) 'Child-friendly urban structures: Bullerby revisited'. J. Environ. Psychol. 35, 110-120.

32. Horelli, L (2007). Constructing a theoretical framework for environmental child-friendliness, Children, Youth, and Environment, 17 (4), pp. 267-292.

33. Nordström, M., (2010) 'Children's views on child-friendly environments in different geographical, cultural and social neighbourhoods', Urban Stud. 47 (3), 514-528.

34. 33. Whitzman, C., Romero, V., Duncan, M. J., Curtis, C., Tranter, P. \& Burke, M. (2010) 'Links between children's Independent Mobility, Active Transport, Physical Activity and Obesity, Preventing Childhood Obesity: Evidence', Policy and Practice, first ed. Joh Wiley \& Sons, Chichester, pp. 105-112.

35. Driskell, D. (2002) 'Creating Better Cities with Children and Youth: A Manual for Participation, Paris: UNESCO' publishing/Earthscan Publications.

36. UNICEF (United Nations International Children's Emergency Fund), (1989). Convention on the Rights of the Child. New York. Available at: https://www.unicef.org./crc/ (Accessed on 25-05-18).

37. 36. Broberg, A., Salminen, S. and Kyttä, M. (2013) 'Physical environmental characteristics promoting independent and active transport to children's meaningful places', Ap. Geogr. 38, 43-52.

38. Oliver, M., Parker, K., Witten, K., Mavoa, S., Badland, H., Donovan, P., Chaudhury, M., Kearns, R.A., 2016. Children's out-of-school independently mobile trips, active travel, and physical activity: a cross-sectional examination from the Kids in the City study. J. Phys. Act. Health 13 (3), 318-324.

39. Schoeppe, S., Duncan, M.J., Badland, H.M., Oliver, M., Browne, M., 2014. Associations between children's independent mobility and physical activity. BMC Public Health, 91.

40. Proshansky, H., Gottlieb, N., 1989. The development of place identity in the child. Zero Three 10 (2), 18-25.

41. Mikkelsen, M. R. \& Christensen, P. (2009). Is children's independent mobility really independent? A study of children's mobility combining ethnography and gps/mobile phone technologies. Motilities, 4, 37-58.
42. Fyhri, A., Hjorthol, R., Mackett, R.L., Fotel, T.N., Kyttä, M., 2011. Children's active travel and independent mobility in four countries: development, social contributing trends and measures. Transp. Policy 18 (5), 703-710.

43. Shaw, B, Bicket, M, Elliott, B, Fagan-Watson, B, Mocca, E, Hillman, M (2015) 'Children's independent mobility', An International Comparison and Recommendations for Action', Pol. Studies Institute, London.

44. 43. Witten, K., Kearns, R., Carroll, P., Asiasiga, L., Tava' e, N., 2013. New Zealand parents' understandings of the intergenerational decline in children' s independent outdoor play and active travel. Children' $\mathrm{S}$. Geogr. http://dx.doi.org/10.1080/ 14733285.2013.7798 City study. Health Place 36, 57-64.

45. Karsten, L (2005) 'It all used to be better? Different generations on continuity and change in urban children's daily use of space', Children's Geographies 3, 275- 290.

46. Pooley, C. G., Turnbull, J. \& Adams, M. (2005) 'Everywhere she went I had to tag along beside her: Family, life course, and everyday mobility in England since the 1940s. The History of the Family, 10, 119-136.

47. Jago, R., Thompson, J, Page, A.S, Brockman, R., Cartwright, K., and Fox, K.R. (2009) 'Licence to be active: parental concerns and 10-11-Year-old children's ability to be independently physically active', Journal of Public Health 31 (4): 472-477.

48. Veitch, J., Bagley, S., Ball, K., Salmon, J., 2006. Where do children usually play? A qualitative study of parents' perceptions of influences on children's active free-play. Health Place 12, 383-393.

49. Mackett, R. L., Brown, B., Gong, Y., Kitazawa, K. \& Paskins, J. (2007). Children's independent movement in the local environment. Built Environment, 33, 454-468.

50. Hillman, M., Adams, J., Whitelegg, J., 1990. One False Move: A Study of Children's Independent Mobility. PSI Publishing, London.

51. Shaw, B, Bicket, M, Elliott, B, Fagan-Watson, B, Mocca, E, Hillman, M (2015) 'Children's independent mobility', An International Comparison and Recommendations for Action', Pol. Studies Institute, London.

52. Prezza, S. Pilloni, C. Sersante, F.R. Alparone, M.V. Giuliani (2011). The influence of psychosocial and environmental factors on children's independent mobility and relationship to peer frequentation J. Community Appl. Soc. Psychol., 11), pp. 435-450

53. UNICEF (United Nations International Children's Emergency Fund), 2009. Child friendly cities promoted by UNICEF national committees and country offices- fact sheet.'

54. Krejcie, R. V. \& Morgan, D. W. (1970) 'Determining Sample Size for Research Activities', Educational and Psychological Measurement, 30, 607-610.

55. Hair, J.F., Hult, G.T.M., Ringle, C.M., and Sarstedt, M (2017) A Primer on Partial Least Squares Structural Equation Modelling (PLS-SEM)., 2^nd^Ed., Thousand Oakes, CA: Sage.

56. Henseler, J., Ringle, C. M., and Sarstedt, M. (2015) 'A New Criterion for Assessing Discriminant Validity in Variance-based Structural Equation Modelling', J. of the Academy of Marketing Science, 43(1): $115-135$

57. Jolliffe, I. T. (2002) 'Principal Component Analysis and Factor Analysis', PCA, 150-166.

58. Badland, H, Donovan P, Mavoa, S et al., (2015) 'Assessing neighbourhood destination access for children: development of the NDAI-C audit tool Environment and Planning B': Plann. and Design 42(6) $1148-1160$.

\section{AUTHORS PROFILE}

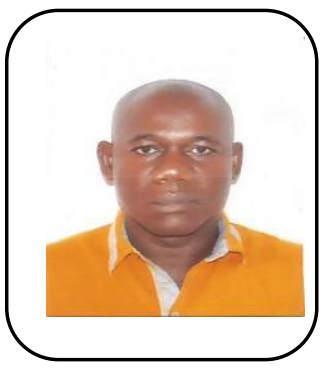

Tosin Daodu was born on Oct 221974 he holds Maters of Technology degree in Architecture. He is currently a Ph.D candidate at the Universiti Teknologi Malaysia and about to submit his Ph.D. thesis. He currently serve with the Nigerian Air Force that released him for study. His research interest is in children's environment, housing management and security studies. He can be reached at daodutosin1@gmail.com 


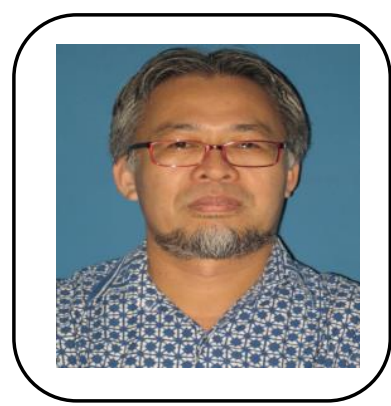

Professor Lar (Dr) Ismail Said holds M.Sc. degree in Landscape Architecture. His research area covers Children's Environment, Urban greening and green infrastructure, Ecosystem services, Carbon Stocking, Urban Morphology and Place Attachment and Vernacular architecture. He has graduated more than $20 \mathrm{PhD}$ students and currently having $18 \mathrm{PhD}$ students under his supervision at Universiti Teknologi He can be reached at ismailbinsaid@gmail.com

John K Ologbonde holds MSc in Housing development and management from university of Ibadan Nigeria. He is currently a lecturer at the department of Quantity Surveying, Rufus Giwa Polytechnic, Owo Ondo state, Nigeria. He can be reached at johnologbonde@gmail.com

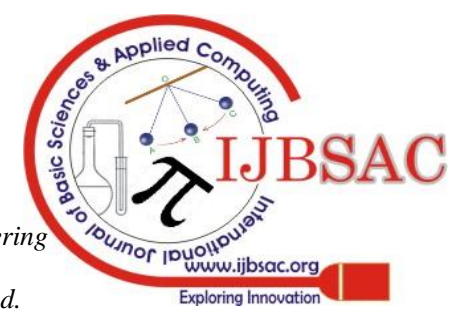

